\title{
Yield Stability of Soybean Genotypes in Tropical Environments based on Genotype and Genotype-by-Environment Biplot
}

\author{
Stabilitas Hasil Genotipe Kedelai pada Lingkungan Tropis \\ Berdasarkan Biplot Genotipe dan Genotipe-Lingkungan
}

\author{
Ayda Krisnawati* and Mochammad Muchlish Adie
}

Indonesian Legumes and Tuber Crops Research Institute

Jl. Raya Kendalpayak Km 8 Malang 65101, East Java, Indonesia

Received 10 October 2017/Accepted 26 July 2018

\begin{abstract}
Genotype $\times$ environment interaction is universal phenomenon when different genotypes are tested in a number of environments. The objective of this experiment was to determine the seed yield stability of soybean genotypes. Seven soybean genotypes and two check cultivars were evaluated at eight soybean production centers during the dry season 2015. Stability analysis on seed yield was based on the GGE biplot method. The combined analysis showed that yield and yield components were significantly affected by genotype $(G)$, environments $(E)$, and genotype $\times$ environment interaction (GEI), except for number of filled pods. The highest yield was G6 (3.07 ton ha $\left.{ }^{-1}\right)$, followed by G7 (2.93 ton ha $\left.{ }^{-1}\right)$. The "whichwon-where" polygon mapping resulted two mega-environments. The best genotype for the first mega-environment was G1 (G511H/Anjasmoro//Anjasmoro-2-8) at E5 (Pasuruan2); and the second one was G6 (G511 H/Anj//Anj///Anj////Anjs-6-7) at E1 (Nganjuk), E2 (Mojokerto), E3 (Blitar), E4 (Pasuruan1), E6 (Jembrana), E7 (Tabanan), and E8 (Central Lombok). The G7 (G511 H/Anjasmoro-1-4-2) was closest to ideal genotype as indicated by relatively stable and produced high yield across environments. The analysis of multi-environment trials data using GGE is useful for determining mega-environment analysis and stability of genotype which focusing on overall performance to identify superior genotypes.
\end{abstract}

Keywords: GE interaction, GGE biplot, Glycine max, seed yield

\section{ABSTRAK}

Interaksi genotipe dengan lingkungan merupakan fenomena umum pada pengujian sejumlah genotipe pada berbagai lingkungan. Tujuan penelitian adalah menentukan stabilitas hasil dari beberapa galur harapan kedelai. Sebanyak 7 galur harapan disertai dua varietas pembanding (Anjasmoro dan Grobogan) dievaluasi pada delapan sentra produksi kedelai selama musim kemarau tahun 2015. Analisis stabilitas hasil biji menggunakan metode GGE biplot. Sidik ragam tergabung menunjukkan bahwa hasil biji dan komponen hasil secara nyata dipengaruhi oleh genotipe $(G)$, lingkungan (E) dan interaksi antara genotipe dan lingkungan (GEI), kecuali jumlah polong isi. Hasil tertinggi diperoleh oleh G6 (3.07 ton ha $\left.{ }^{-1}\right)$ diikuti oleh G7 (2.93 ton $\mathrm{ha}^{-1}$ ). Grafik poligon "which-won-where” mampu mengelompokkan lingkungan pengujian menjadi dua mega lingkungan. Galur terbaik pada mega lingkungan pertama (E1/Pasuruan2) adalah G1 (G511H/Anjasmoro//Anjasmoro2-8), sedangkan galur terbaik pada mega lingkungan kedua (E1/Nganjuk), E2/Mojokerto), E3/Blitar, E4/Pasuruan1, E6/ Jembrana, E7/Tabanan, dan E8/Lombok Tengah) adalah G6 (G511 H/Anj//Anj///Anj////Anjs-6-7). Genotipe terpilih yang terindikasi sebagai genotipe ideal adalah $G 7$ (G511 H/Anjasmoro-1-4-2), yakni hasil relatif stabil dan berdaya hasil tinggi pada berbagai lingkungan. Analisis GGE pada penelitian secara lintas lingkungan berguna untuk menentukan mega lingkungan dan mengidentifikasi genotipe yang stabil dengan menekankan pada keragaan keseluruhan tanaman dalam identifikasi genotipe superior.

Kata kunci: biplot GGE, Glycine max, hasil biji, interaksi GE

\section{INTRODUCTION}

Soybean (Glycine max L. Merrill) is a major legume crops in Indonesia, which is cultivated in various agro-

\footnotetext{
* Corresponding author. e-mail: my_ayda@yahoo.com
}

ecologies. Environmental conditions such as the growing season, cropping patterns, soil characteristics, temperature, photoperiod, and rainfall; determine the adaptability of each soybean variety. As a result, the performance of soybean cultivars is influenced by interaction with these environments [genotype $\times$ environment interaction $(\mathrm{GEI})$ ]. 
A multi-environment trial over several environments and years is a way to overcome the GEI problem, to recognize the selected genotype with high and stable performance over a wide range of environments (Gedif et al., 2014; Rincent et al., 2017; Tariku, 2017).

GEI is defined as the failure of genotypes to achieve a consistentphenotypicperformanceoverdiverseenvironments (Aswaf et al., 2009), and it was resulted from the differential responses of genotypes across a range of environment. The presence of GEI was indicated by the differential ranking of genotypes over the various environments. Thus, this occurrence will reduce the correlation between phenotypic and genotypic values and complicates the selection process of the best genotypes (Rea et al., 2016). GEI can be formed as qualitative (crossover) interaction or quantitative (noncrossover) interaction. Non-crossover type interaction, or the absence of GEI, is preferred when selecting genotypes for wide adaptation (Matus-Cadiz et al., 2003), by selecting genotype that has good mean performance over a wide range of environments (Gurmu et al., 2009). However, the presence of crossover type interaction is important, because it implies that the choice of the best genotype is determined by the environment (Malosetti et al., 2012), hence, the breeding environments may be classified in to mega-environments and specifically adapted genotypes can be developed for each sub environment separately (Yan et al., 2007). Mega environments is defined as a group of locations or environments that constantly share the same best genotypes (Yan et al., 2000).

Numerous statistical methods have been proposed to analyze and determine the results of multi-location trials and GEI data (Ilker et al., 2009; Tukamuhabwa et al., 2012; Mitrovic et al., 2012). There are two major groups of stability statistic, i.e. univariate and multivariate methods (Adugna 2008; Szareski et al., 2017). The newest popular multivariate method is GGE, which stands for the genotype main effect (G) and the genotype $\times$ environment interaction (GE). GGE biplot is an effective method to quantify the GEI effects, which is based on principal component analysis (PCA). GGE analysis partitions G + GE into principal components through singular value decomposition of environmentally centered yield data (Yan, 2001). GGE-biplot graph shows which genotype won in which environments ('whichwon-where"), and thus provides mega-environments identification (Yan et al., 2000; Alwala et al., 2010).

GGE biplot methodology has been recognize as useful method which provides comprehensive visualization of the GEI pattern of multi-environmental trials, and has been widely used in various crops, i.e., soybean (Amira et al., 2013), maize (Sibiya et al., 2013), mungbean (Ullah et al., 2012), and sorghum (Rakshit et al., 2012). This method is important for mega-environment analysis, genotype evaluation (mean vs. stability), and test environment evaluation which provides discriminating power vs. representativeness of the test environment (Yan et al., 2007; Jalata, 2011; Atnaf et al., 2013).

The objective of this study was to determine the seed yield stability of soybean promising lines by using GGE biplot method.

\section{MATERIALS AND METHODS}

The materials used nine soybean genotypes, consisting of seven lines and two check cultivars ('Anjasmoro' and 'Grobogan', Table 1). The field trials were conducted at eight soybean production centers (Nganjuk, Mojokerto, Blitar, Pasuruan1, Pasuruan2, Jembrana, Tabanan, and Central Nusa Tenggara) in 2015 (Table 2). The field experimental design for each location was randomized block design with four replicates. Each genotype was planted on $2.4 \mathrm{~m} \mathrm{x} 4.5$ m plot size, with $40 \mathrm{~cm} \times 15 \mathrm{~cm}$ planting distance, and two seeds/hole. Fertilizer of $50 \mathrm{~kg} \mathrm{ha}^{-1}$ Urea, $100 \mathrm{~kg} \mathrm{ha}^{-1} \mathrm{SP} 36$ and $75 \mathrm{~kg} \mathrm{ha}^{-1} \mathrm{KCl}$ were applied at sowing. Pests, diseases, and weeds were controlled optimally, and drainage was applied to maintain optimum soil moisture. Pod was harvested when $95 \%$ of the leaf turned yellow in a population. Seed yield was recorded and analyzed by randomly taken from the seed yield per plot and converted to ton $\mathrm{ha}^{-1}$. The following yield components were measured on all plots at each location: days to maturity, plant height, number of branches, number of nodes, number of filled pods, and 100 seed weight.

Combined analysis of variance for yield and yield components was used to determine the effects of genotype (G), environment (E) and genotype $\mathrm{x}$ environment interaction. Stability analysis on seed yield was based on singular value decomposition that is represented by GGE (Genotype and Genotype x Environment) Biplot.

The GGE model is $Y_{i j r}=\mu+e_{j}+\sum_{k=1} \lambda_{k} \alpha_{i k} \gamma_{j k}+\varepsilon_{i j r}$,

where $Y_{i j r}$ is observation of the $r^{\text {th }}$ replicate of the $i^{\text {th }}$ genotype in the $j^{\text {th }}$ environment, $\mu$ is the overall mean, $e_{j}$ is main effect of the $j^{\text {th }}$ environment, $x$ is matrix rank $\{g g e\}_{i j}$ when $g g e_{i j}$ $=g_{i}+g e_{i j}, \lambda_{k}$ is the singular value for principal component $k, \alpha_{i k}$ is the eigenvector score for genotype $i$ and component $k, \gamma_{j k}$ is the eigenvector score for environment $j$ and component $k \varepsilon_{i j r}$ and is the error for genotype $i$ and environment $j$ and replicate $r$.

The results of GGE analysis were presented by analysis of variance and biplot graph. A biplot was an enhanced scatter plot that summarizing two factors in such

Table 1. Genotype and genotype code in soybean multienvironment trials at 8 locations

\begin{tabular}{llc}
\hline No. & \multicolumn{1}{c}{ Genotype } & $\begin{array}{c}\text { Genotype } \\
\text { Code }\end{array}$ \\
\hline 1 & G511H/Anjasmoro//Anjasmoro-2-8 & G1 \\
2 & G511H/Arg//Arg///Arg///Arg-12-15 & G2 \\
3 & G511H/Anj// Anj///Anj-6-3 & G3 \\
4 & G511H/Arg//Arg///Arg///Arg-19-7 & G4 \\
5 & G511H/Anjasmoro-1-7 & G5 \\
6 & G511 H/Anj//Anj///Anj////Anjs-6-7 & G6 \\
7 & G511 H/Anjasmoro-1-4-2 & G7 \\
8 & 'Anjasmoro' & G8 \\
9 & 'Grobogan' & G9 \\
\hline
\end{tabular}


Table 2. Location, code and characteristic of the multi-environment trials

\begin{tabular}{|c|c|c|c|c|c|c|c|c|}
\hline No. & Location & Code & Soil Type & $\begin{array}{l}\text { Land } \\
\text { Type }\end{array}$ & $\begin{array}{l}\text { Previous } \\
\text { crop }\end{array}$ & $\begin{array}{c}\text { Planting date / } \\
\text { Environment }\end{array}$ & Climate $^{\mathrm{a}}$ & $\begin{array}{l}\text { Altitude } \\
\text { (masl) }^{\mathrm{b}}\end{array}$ \\
\hline 1 & $\begin{array}{l}\text { Jati Kampir Village, Bagor } \\
\text { District, Nganjuk Regency }\end{array}$ & E1 & Regosol & Lowland & paddy & $\begin{array}{c}24 \text { February } 2015 \\
\text { (dry season I) }\end{array}$ & $\mathrm{C} 3$ & 58 \\
\hline 2 & $\begin{array}{l}\text { Kedunguneng Village, } \\
\text { Bangsal District, Mojokerto } \\
\text { Regency }\end{array}$ & E2 & Vertisol & Lowland & paddy & $\begin{array}{l}20 \text { March } 2015 \\
\text { (dry season I) }\end{array}$ & $\mathrm{C} 3$ & 72 \\
\hline 3 & $\begin{array}{l}\text { Binangun Village, Kesamben } \\
\text { District, Blitar Regency }\end{array}$ & E3 & Entisol & Upland & maize & $\begin{array}{l}22 \text { February } 2015 \\
\text { (dry season I) }\end{array}$ & $\mathrm{C} 3$ & 355 \\
\hline 4 & $\begin{array}{l}\text { Sumber Banteng Village, } \\
\text { Kejayan District, Pasuruan } \\
\text { Regency }\end{array}$ & E4 & Alfisol & Upland & maize & $\begin{array}{l}10 \text { January } 2015 \\
\text { (dry season I) }\end{array}$ & $\mathrm{E}$ & 124 \\
\hline 5 & $\begin{array}{l}\text { Sumber Banteng Village, } \\
\text { Kejayan District, Pasuruan } \\
\text { Regency }\end{array}$ & E5 & Alfisol & Lowland & soybean & $\begin{array}{l}26 \text { June } 2015 \\
\text { (dry season II) }\end{array}$ & E & 124 \\
\hline 6 & $\begin{array}{l}\text { Budeng Village, Jembrana } \\
\text { District, Jembrana Regency }\end{array}$ & E6 & Entisol & Lowland & paddy & $\begin{array}{l}10 \text { April } 2015 \\
\text { (dry season I) }\end{array}$ & D2 & 168 \\
\hline 7 & $\begin{array}{l}\text { Beraban Village, Kediri } \\
\text { District, Tabanan Regency }\end{array}$ & E7 & Inceptisol & Lowland & paddy & $\begin{array}{l}6 \text { March } 2015 \\
(\text { dry season I) }\end{array}$ & $\mathrm{D} 2$ & 174 \\
\hline 8 & $\begin{array}{l}\text { Segala Anyar Village, Pajut } \\
\text { District, Central Nusa } \\
\text { Tenggara Regency }\end{array}$ & E8 & Inceptisol & Lowland & paddy & $\begin{array}{l}10 \text { March } 2015 \\
\text { (dry season I) }\end{array}$ & D3 & 20 \\
\hline
\end{tabular}

Note: aclimate type based on Oldeman classification system: C3 $=5-6$ wet months and 4-6 dry months, D2 $=3-4$ wet months and 2-3 dry months, D3 = 3-4 wet months and 4-6 dry months, $\mathrm{E}=<3$ wet months and $<2$ dry months; ${ }^{\mathrm{m}}$ masl $=$ meter above sea level

a way that relationships among the factors and underlying interactions between them can be visualized. The GGE biplot showed the first two principal components (PC1 and PC2, also referred as primary and secondary effects, respectively) derived from subjecting environment centered yield data (the yield variation due to GGE) to singular value decomposition. The first interaction principal component axes (IPCA1) represented genotype productivity, and the second interaction principal component axes (IPCA2) described the genotype stability (Yan et al., 2000; Rakshit et al., 2012).

The best genotype in each environment and megaenvironment differentiation was identified by a polygon that exposed the pattern of "which-won-where" (Gedif et al., 2014). "Which-won-where" graph was created by joining the most distance genotypes to form a polygon. Furthermore, perpendicular lines were drawn, starting from the origin of the biplot to each side of the polygon and dividing the biplot into several sectors with one genotype at the vertex of the polygon. Within a sector, genotype located at the vertex polygon is the best genotypes in all environments in the sector, and genotypes are well adapted in environments that are in the same sector (Yan, 2001). Performance of yield and stability of a genotype were evaluated by the method of average environment coordinate or AEC (Yan, 2001; Yan and Hunt, 2002; Yan, 2002).

\section{RESULTS AND DISCUSSION}

Analysis of variance showed that for seed yield the interaction between genotype $\times$ environment $(\mathrm{GEI})$ was significant $(\mathrm{p}<0.001)$, with GEI significantly explained $36.15 \%$ of the total variation. However, the occurrence of GEI in multi-environment trials is inevitable, due to the presence of either genetic diversity or the diverse in agro ecology. The magnitude of the GEI effect was larger than that for genotypes, indicating that there were considerable differences in genotypic response across environments. This result is in agreement with those of Rasyad and Idwar (2010) and Purbokurniawan et al. (2014). Another research found the E effect was about three times higher than $G$ and GE effects (Cravero et al., 2010). Suwarto (2010) also reported that $E$ attributed to $74.43 \%$ of the total variation, while $G$ and GE each explained for about 5.60\% and $19.67 \%$ of variation, respectively.

The average seed yield of nine soybean genotypes was 2.65 ton $\mathrm{ha}^{-1}$ (Table 3). The highest yield was G6 (3.07 ton $\left.\mathrm{ha}^{-1}\right)$, followed by G7 (2.93 ton $\left.\mathrm{ha}^{-1}\right)$, and the lowest yield was G3 (2.41 ton ha $\left.{ }^{-1}\right)$. The yield of check cultivars G8 and G9 (Anjasmoro and Grobogan) were 2.47 and 2.44 ton ha ${ }^{-1}$, respectively. A total six lines produced higher yield than the check cultivars, but only four lines (G2, G4, G6, and G7) showed higher than the average yield. 
GEI refers to inconsistent phenotypic performance of genotypes across environments, which can be formed as quantitative interactions (non-crossover type) in which case there is no change in ranking of genotypes; or qualitative interactions (crossover type) when there is changes in the relative ranking of the genotypes (Ayalew et al., 2014). In this study, the GEI was a crossover type, as revealed by differential yield ranking of genotypes across environments trial (Table 3). Genotype G6 was the top ranking at four environments while G1, G2, G4, and G7, each was top ranking at one environment. G7 recorded the top yield 3.72 ton $\mathrm{ha}^{-1}$ at the highest yielding environment (E1) whereas G2 was the highest yielder ( 2.60 ton $\left.\mathrm{ha}^{-1}\right)$ at the lowest yielding environment (E5).

Analysis of variance for GGE is presented in Table 4. The partitioning of the $\mathrm{G}+\mathrm{GE}$ sum of squares through GGE biplot showed that PC1 and PC2 were significant components that explained $61.49 \%$ and $18.84 \%$ of $\mathrm{G}+$ GE sum of squares, respectively. The presence of GEI was clearly demonstrated by the GGE model, when the interaction was partitioned among the first two interaction principal component axes, as they were significant $(\mathrm{P}<0.001)$. Due to the presence of GEI, yield become unpredictable and cannot be interpreted only based on genotype and environmental means (Hongyu et al., 2014; Rea et al., 2016). Furthermore, these imply that the interaction of nine soybean genotypes with eight environments was predicted by the first two principal components of genotypes and environments.

The pattern of "which-won-where" polygon showed the biplot was divided into five sectors (S1 to S5) with different winning genotypes, and the environments fall into two of them (Figure 1). Seven environments (E1, E2, E3, E4, E6, E7, and E8) fell into sector 1 (S1) and the vertex genotype for this sector was genotype 6 (G6). A single environment, E5 fell into sector 5 (S5). The vertex genotype for this sector was genotype 1 (G1). These sectors (S1 and S5) were identified as two mega-environments. The polygon also explores associations between genotypes and environments. In this case, G1 was the winning genotype in E5, whilst G6 as the wining genotype in the rest of the E areas. Within S1, genotype G1, G4, and G7 performed well in all $\mathrm{E}$ areas except E5. Furthermore, within S5, genotype G1 and G2 were shows better performance in E5 than within other test environments. G3, G5, G8, and G9 had poor yield performance over tested environments.

The length of an environmental vector is related to the discriminating power of the environment, and it is proportional to the standard deviation of genotypes in that particular environment. This is also served as an estimation of discriminating power of the environment, but if the experimental errors of the test environments are comparable (Yan et al., 2007). In this study, E3 as well as E8 as the

Table 3. Mean seed yield (ton ha $\mathrm{a}^{-1}$ ) of the 9 soybean genotypes (G1 to G9) in 8 environments (E1 to E8)

\begin{tabular}{|c|c|c|c|c|c|c|c|c|c|}
\hline \multirow{2}{*}{ Code } & \multicolumn{8}{|c|}{ Environments $^{\mathrm{a}}$} & \multirow{2}{*}{ Mean $^{\mathrm{b}}$} \\
\hline & E1 & E2 & E3 & E4 & E5 & E6 & E7 & E8 & \\
\hline G1 & 2.71 & 2.67 & 3.16 & 2.46 & 2.24 & 2.68 & 2.46 & 2.33 & $2.59 \mathrm{cde}$ \\
\hline $\mathrm{G} 2$ & 2.95 & 2.24 & 2.87 & 2.69 & $\underline{2.60}$ & 2.82 & 2.51 & 2.60 & $2.66 \mathrm{~cd}$ \\
\hline G3 & 2.52 & 2.30 & 2.16 & 2.26 & 2.32 & 2.43 & 2.76 & 2.56 & $2.41 \mathrm{e}$ \\
\hline G4 & 2.99 & 2.43 & 2.49 & $\underline{2.93}$ & 2.06 & 3.08 & 2.95 & 3.05 & $2.75 b c$ \\
\hline G5 & 3.03 & 2.44 & 2.07 & 1.98 & 2.05 & 2.52 & 2.76 & 3.10 & 2.49de \\
\hline G6 & 3.71 & 2.61 & $\underline{3.49}$ & 2.42 & 2.03 & $\underline{3.40}$ & $\underline{3.51}$ & $\underline{3.42}$ & $3.07 \mathrm{a}$ \\
\hline G7 & $\underline{3.72}$ & 2.25 & 2.96 & 2.72 & 2.44 & 3.17 & 3.20 & 3.03 & $2.94 \mathrm{ab}$ \\
\hline G8 & 2.75 & 2.07 & 2.53 & 1.91 & 2.20 & 2.98 & 2.63 & 2.68 & $2.47 \mathrm{de}$ \\
\hline G9 & 2.65 & 2.33 & 2.49 & 2.26 & 2.52 & 2.43 & 2.43 & 2.47 & $2.45 \mathrm{e}$ \\
\hline Mean & 3.00 & 2.37 & 2.69 & 2.40 & 2.27 & 2.83 & 2.80 & 2.80 & 2.65 \\
\hline
\end{tabular}

Note: anderlined values are highest yields at each test environments. ${ }^{b}$ Value within the same column followed by the same letter are not significantly different at the 0.05 level according to LSD test

Table 4. Analysis of variance for GGE

\begin{tabular}{lcccr}
\hline Principal component & Degree of freedom & Eigen values & Total Eigen values (\%) & Cumulative (\%) \\
\hline PC1 & 14 & $19.4299^{* *}$ & 61.500 & 61.50 \\
PC2 & 12 & $5.9528^{* *}$ & 18.842 & 80.34 \\
Residual & 30 & 6.213 & 19.658 & 100.00 \\
Total Eigen values* & & $31.5959^{*}$ & & \\
\hline
\end{tabular}

Note: $*=$ total of Eigen values are equal with total of $\mathrm{G}+\mathrm{GE}$ sum of squares; ** = significant at $\alpha 1 \%(\mathrm{p}<0.01)$ 


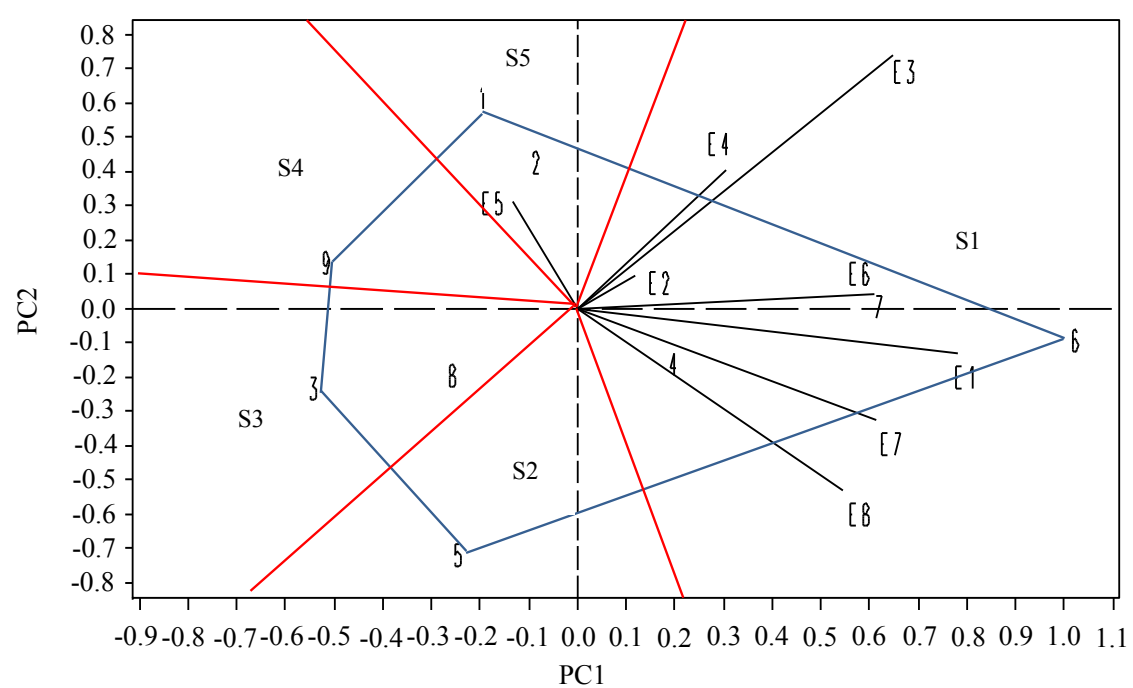

Figure 1. Polygon views of the GGE-biplot based on symmetrical scaling for the "which-won where pattern". S = sector (S1- S5), E = environment (E1-E8), number 1-9 represent genotype 1-9

environments with longer vectors were more discriminating of the genotypes for seed yield. If an environment is close to the biplot origin, as E2 and E5 (Figure 1), meaning that those genotypes performed similarly and therefore resulted in insufficient information about the differences of genotypes' yield. Furthermore, a high discriminating environment maximizes the observed genotypic variation among genotypes for a given trait. The efficiency and accuracy within selection of genotype for a particular trait is greatly enhanced in high discriminating environments compared with non-discriminating ones (Cravero et al., 2010).

Evaluation of performance for yield and stability of a genotype was illustrated by an average environment coordinate (AEC) as defined by the mean PC1 and PC2 scores of environments, and was illustrated by a small circle on the GGE biplot graph (Figure 2). AEC abscissa is the single line (blue line) that passes through the biplot origin, whereas the AEC ordinate is the single line (green line) that passes through the biplot origin and is perpendicular to the AEC abscissa (Figure 2). AEC ordinate separates genotypes which had seed yield higher than the general average with genotypes which had seed yield lower than the general average. Genotypes with seed yield higher than the general average were G1, G2, G4, G6, and G7, whereas G3, G5, G8, and G9 produce yield lower than the general average. The highest yielding genotype was G6 followed by G7. AEC ordinate, either direction away from the biplot origin indicates a greater GEI effect and reduced stability (Yan,

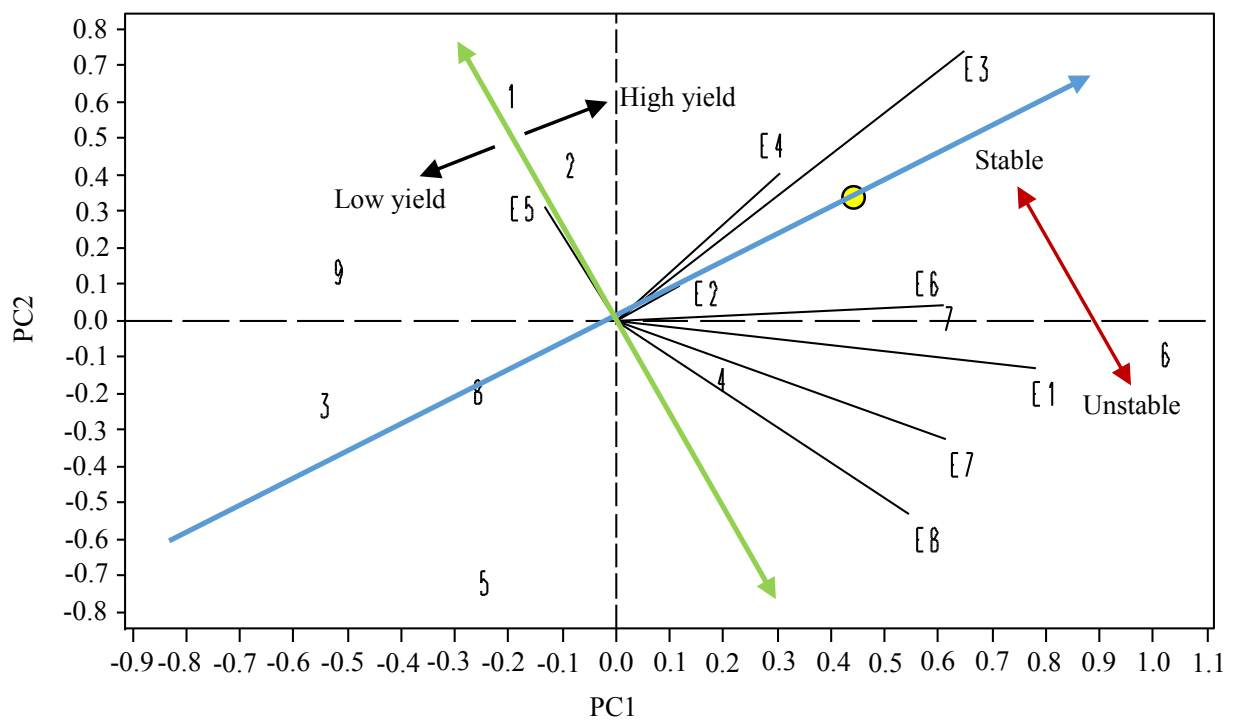

Figure 2. Average environment coordinate (AEC) of the GGE Biplot based on symmetrical scaling. Straight line (square dot) passing through AEC (black dot) with the biplot origin as AEC abscissa, a straight line (long dash) through the origin and perpendicular biplot as AEC ordinate. Directions to the AEC ordinate that move away from the biplot origin showed increased stability. AEC ordinate split genotypes under general average (low yield) and above the general average (high yield). $\mathrm{E}=$ environment (E1-E8), number 1-9 represent genotype $1-9$ 
2002; Yan and Hunt, 2002). Thus, the most stable genotype was G8, followed by G3, G4, and G7.

The yield of G8 and G3 as stable genotypes, as it located near the AEC abscissa, produce yield below average. G4 which also categorized as stable, showed average performance. G7 had similar yield stability with G4, occupy the second highest yield. On the other hand, the highest yielding genotype (G6) was located far away from the AEC abscissa, indicates more responsive to the environment change (unstable). But since an ideal cultivar, as proposed by Yan et al., (2007), should have both high mean performance and high stability within a megaenvironment, hence, G7 was considered as the closest genotype to the ideal cultivar, followed by G4. The closest ideal genotype, G7, performed best at E1, while near average yielded at E2 and E5. According to Rakshit et al. (2012), it would be difficult to conceive from mean table alone (Table 3 ), since the presence of high crossover GEI, i.e. the rank of genotypes' performance varied depend on the testing environment. However, varieties that are adapted to wider environments become the breeders' main goal, since it is easier and cost effective both in terms of variety evaluation and seed multiplication (Matus-Cadiz et al., 2003; James and Lawn, 2011).

According to the GGE biplot analysis, there are two ideal test environments, i.e. environments with large PC1 scores (more power to discriminate genotypes in terms of the genotypic main effect) and small (absolute) PC2 scores (more representative of the overall environments) (Yan et al., 2000; Yan and Rajcan, 2002). The first environment is useful for clearly sorting the differences between genotypes. This environment is useful for testing the segregated population. The second environment is useful for selecting the best genotype for a trait, without having to test at multiple locations. The selection results at this location reflect the test results at other locations (Suwarto, 2010). Thus, the ideal test environment for discriminating genotypes was E1, and E6 as the representative environment for soybean yield testing.

The analysis of variance on agronomic characters of yield components (Table 5) showed significant GEI for all parameters studied, except for number of filled pod. The mean performance of yield components of nine genotypes in pooled environments was presented in Table 6, whereas the mean performance of yield components of eight environments in pooled genotypes was presented in Table 7.

Table 5. Analysis of variance for yield components of 9 genotypes in 8 environments

\begin{tabular}{|c|c|c|c|c|c|c|c|}
\hline \multirow{2}{*}{ Parameter } & \multicolumn{3}{|c|}{ Mean Square } & \multirow{2}{*}{$\sigma_{\mathrm{e}}^{2}$} & \multirow{2}{*}{$\sigma_{\mathrm{g}}^{2}$} & \multirow{2}{*}{$\sigma_{\mathrm{ge}}^{2}$} & \multirow{2}{*}{$\begin{array}{l}\text { CV } \\
(\%)\end{array}$} \\
\hline & Environment (E) & Genotype (G) & $\mathrm{G} \times \mathrm{E}$ & & & & \\
\hline Days to maturity (day) & $58.88 * *$ & $133.61 * *$ & $3.33 * *$ & 1.24 & 4.07 & 0.52 & 1.42 \\
\hline Plant height (cm) & $3,195.99 * *$ & $1,596.23 * *$ & $111.04 * *$ & 48.67 & 46.41 & 15.59 & 11.64 \\
\hline Number of branches/plant & $7.36^{* *}$ & $6.00 * *$ & $0.97 *$ & 0.64 & 0.15 & 0.08 & 38.08 \\
\hline Number of node/plant & $65.53 * *$ & $23.78 *$ & $8.82 * *$ & 9.58 & 0.46 & 0.00 & 23.54 \\
\hline Number of filled pod/plant & $1,292.55 * *$ & $331.47 * *$ & $112.38 \mathrm{~ns}$ & 90.02 & 6.84 & 5.58 & 21.05 \\
\hline 100 seed weight $(\mathrm{g})$ & $51.95 * *$ & $89.67 * *$ & $5.01 * *$ & 1.61 & 2.64 & 2.64 & 7.48 \\
\hline
\end{tabular}

Note: $* *=$ significant at $\alpha 1 \%(\mathrm{p}<0.01), *=$ significant at $\alpha 5 \%(\mathrm{p}<0.05), \mathrm{CV}=$ coefficient of variation

Table 6. Yield components of 9 genotypes in pooled environments

\begin{tabular}{lcccrcc}
\hline \multirow{2}{*}{ Code } & \multicolumn{7}{c}{ Yield components } \\
\cline { 2 - 7 } & DTM & PH & NOB & NON & NOP & SW \\
\hline G1 & $74-79$ & $39.75-59.34$ & $1.75-3.42$ & $11.50-15.59$ & $34.09-53.75$ & $15.31-20.97$ \\
G2 & $74-78$ & $50.50-72.34$ & $1.45-3.42$ & $9.75-14.67$ & $35.95-46.25$ & $14.44-18.94$ \\
G3 & $77-83$ & $43.50-82.59$ & $0.25-2.25$ & $10.38-16.42$ & $33.35-58.75$ & $14.12-18.03$ \\
G4 & $75-81$ & $48.75-73.42$ & $1.63-3.50$ & $11.25-15.92$ & $30.50-55.34$ & $14.43-18.69$ \\
G5 & $77-82$ & $49.10-89.42$ & $0.13-3.25$ & $9.38-16.75$ & $28.30-56.88$ & $14.59-19.69$ \\
G6 & $77-82$ & $58.75-95.25$ & $1.75-3.67$ & $11.50-17.75$ & $35.27-64.50$ & $14.26-18.13$ \\
G7 & $77-81$ & $56.00-92.08$ & $1.80-3.00$ & $11.50-17.17$ & $35.81-59.50$ & $14.49-16.06$ \\
G8 & $81-84$ & $56.75-91.92$ & $1.75-2.50$ & $11.25-17.75$ & $36.10-59.00$ & $15.44-17.19$ \\
G9 & $74-78$ & $43.50-64.33$ & $1.30-2.67$ & $9.75-14.25$ & $32.45-47.00$ & $16.66-25.37$ \\
\hline Mean & 77 & 56.43 & 2.76 & 15.13 & 43.17 & 16.27 \\
\hline
\end{tabular}

Note: $\mathrm{DTM}=$ Days to maturity (days), $\mathrm{PH}=$ Plant height $(\mathrm{cm}), \mathrm{NOB}=$ Number of branches per plant, $\mathrm{NON}=$ Number of node per plant, $\mathrm{NOP}=$ Number of filled pod per plant, $\mathrm{SW}=100$ seed weight $(\mathrm{g})$ 
Most of genotypes have early days to maturity $(<80$ days $)$, except G8 which had medium maturity. All genotypes have large seed size ( $>14 \mathrm{~g} / 100$ seed).

The farmers' preference of soybean improved variety were not only had high yield and performance over of a wide range of environments, but also must have the early days to maturity and large seed size (Krisdiana 2014). In this study, the stable genotypes were G8, G3, G7, and
G4. However, based on their yields, only G7 with highest yield performance among them (Table 3 ). This genotype (G7) have early days to maturity, large seed size, and also produced the highest number of filled pods (Table 6). These agronomic characters are preferred by farmers, thus this genotype could be categorized as ideal genotype and could be recommended to be released as new improved soybean variety.

Table 7. Yield components of 8 environments in pooled genotypes

\begin{tabular}{lcccccc}
\hline \multirow{2}{*}{ Code } & \multicolumn{7}{c}{ Yield components } \\
\cline { 2 - 7 } & DTM & PH & NOB & NON & NOP & SW \\
\hline E1 & $76-82$ & $50.08-77.17$ & $0.84-3.33$ & $12.67-17.33$ & $30.50-59.50$ & $14.84-22.79$ \\
E2 & $74-82$ & $48.25-66.75$ & $1.75-3.25$ & $10.25-14.75$ & $40.50-56.88$ & $14.49-17.76$ \\
E3 & $75-82$ & $59.34-94.25$ & $0.75-3.67$ & $12.50-17.75$ & $39.08-64.50$ & $16.06-25.37$ \\
E4 & $76-82$ & $44.00-71.40$ & $0.25-2.20$ & $10.20-14.85$ & $28.30-40.95$ & $15.44-16.66$ \\
E5 & $74-81$ & $46.50-68.88$ & $0.13-2.25$ & $9.38-15.00$ & $33.79-38.38$ & $15.67-19.73$ \\
E6 & $77-82$ & $43.50-58.75$ & $1.75-2.75$ & $11.75-16.75$ & $45.50-58.50$ & $14.12-21.50$ \\
E7 & $76-83$ & $47.75-68.50$ & $0.83-2.67$ & $9.75-12.42$ & $36.92-50.42$ & $15.25-21.59$ \\
E8 & $78-84$ & $39.75-69.75$ & $1.25-2.50$ & $10.75-14.50$ & $37.50-59.00$ & $15.68-23.57$ \\
\hline Mean & 78 & 59.9 & 2.11 & 13.15 & 45.06 & 16.97 \\
\hline
\end{tabular}

Note: $\mathrm{DTM}=$ Days to maturity (days), $\mathrm{PH}=$ Plant height $(\mathrm{cm}), \mathrm{NOB}=$ Number of branches per plant, $\mathrm{NON}=$ Number of node per plant, $\mathrm{NOP}=$ Number of filled pod per plant, $\mathrm{SW}=100$ seed weight $(\mathrm{g})$

\section{CONCLUSION}

The combined analysis showed that yield and yield components were significantly affected by GEI, except for number of filled pods. The significant GEI in soybean yield revealed differential response of the genotypes across testing environments. The "which-won-where" polygon graph of GGE results two mega-environments. The best genotype for the first mega-environment was G1 (G511H/Anjasmoro// Anjasmoro-2-8) at E5 (Pasuruan2); and the second one was G6 (G511 H/Anj//Anj///Anj////Anjs-6-7) at E1 (Nganjuk), E2 (Mojokerto), E3 (Blitar), E4 (Pasuruan1), E6 (Jembrana), E7 (Tabanan), and E8 (Central Nusa Tenggara). According to GGE stability análisis, genotypes G8 (Anjasmoro), G3 (G511H/Anj// Anj///Anj-6-3), G7 (G511 H/Anjasmoro1-4-2), and G4 (G511H/Arg//Arg///Arg///Arg-19-7) were found to be stable. However, only G7 produced the highest yield performance across environments among the stable genotypes, and thus, it is recommended to be proposed as new soybean variety with stable yield performance. The GGE biplot method was found useful for visualize the interaction between genotypes and environments, identifying environments/locations that optimize genotypes performance, and the performance of yield and stability.

\section{ACKNOWLEDGEMENTS}

The authors would like to acknowledge the financial support provided by Indonesian Agency for Agricultural Research and Development (IAARD). The author also thank Arifin and Antoni for managing the field trials, and for all person who has helped in collecting data.

\section{REFERENCES}

Adugna, A. 2008. Assessment of yield stability in sorghum using univariate and multivariate statistical approaches. Hereditas 145:28-37.

Alwala, S., T. Kwolek, M. McPherson, J. Pellow, D. Meyer. 2010. A comprehensive comparison between Eberhart and Russell joint regression and GGE biplot analyses to identify stable and high yielding maize hybrids. Field Crops Res. 119:225-230.

Amira, J.O., D.K. Ojo, O.J. Ariyo, O.A. Oduwaye, M.A. Ayo-Vaughan. 2013. Relative discriminating powers of GGE and AMMI models in the selection of tropical soybean (Glycine max L. Merr.) genotypes. Afr. Crop Sci. J. 21:67-73.

Asfaw, A., F. Alemayehu, F. Gurum, M. Atnaf. 2009. AMMI and SREG GGE biplot analysis for matching varieties onto soybean production environments in Ethiopia. Sci. Res. Essays 4:1322-1330.

Atnaf, M., S. Kidane, S. Abadi, Z. Fisha. 2013. GGE biplots to analyze soybean multi-environment yield trial data in North Western Ethiopia. J. Plant Breeding Crop Sci. 5:245-254. 
Ayalew, H., L. Wondale, A. Teshager. 2014. GGE biplot analysis on the performance of wheat genotype for hectolitre weight and mega environments identification in North Western Ethiopia. Australian J. Crop Sci. 8:1435-1440.

Cravero, V., M.A. Esposito, F.L. Anido, S.M. Garcia, E. Cointry. 2010. Identification of an ideal test environment for asparagus evaluation by GGE-biplot analysis. Australian J. Crop Sci. 4:273-277.

Gedif, M., D. Yigzaw, G. Tsige. 2014. Genotypeenvironment interaction and correlation of some stability parameters of total starch yield in potato in Amhara region, Etiopia. J. Plant Breeding Crop Sci. 6:31-40.

Gurmu, F., M. Hussein, G. Alemaw. 2009. Genotype x environment interactions and stability of soybean for grain yield and nutrition quality. Afr. Crop Sci. J. 17:87-99.

Hongyu, K., M. Garcia-Pena, L.B. de Araujo, C.T.S. Dias. 2014. Statistical analysis of yield trials by AMMI analysis of genotype $\mathrm{x}$ environment interaction. Biometrical Letters 51:89-102.

Ilker, E., T. F Aykut, O. Caylak, M. Tosun, I. Ozmen. 2009. Assessment of genotype $\mathrm{x}$ environment interactions for grain yield in maize hybrids using AMMI and GGE biplot analysis. Turkish J. Field Crops 14:123135.

Jalata, Z. 2011. GGE-biplot analysis of multi-environment yield trials of barley (Hordeium vulgare. L.) genotypes in Southeastern Ethiopia Highlands. Internat. J. Plant Breeding Genet. 5:59-75.

James, A.T., R.J. Lawn. 2011. Application of physiological understanding in soybean improvement. II. 2 Broadening phenological adaptation across regions and sowing dates. Crop Pasture Sci. 62:12-24.

Krisdiana, R. 2014. The distribution of improved soybean varieties and their impact on the rural economy. J. Penelitian Pert. Tan. Pangan 33:61-69.

Malosetti, M., J. Ribaut, F.A van Eeuwijk. 2012. The stastistical analysis of multi-environment data: modeling genotype-by-environment interaction and its genetic basis. Front. Physiol. 4:44.

Matus-Cadiz, M.A., P. Hucl, C.E. Perron, R.T. Tyler. 2003. Genotype $\times$ environment interaction for grain color in hard white spring wheat. Crop Sci. 43:219-226.
Mitrovic, B., D. Stanisavljevi, S. Treski, M. Stojakovic, M. Ivanovic, G. Bekavac, M. Rajkovic. 2012. Evaluation of experimental maize hybrids tested in multilocation trials using AMMI and GGE biplot analysis. Turkish J. Field Crops 17:35-40.

Purbokurniawan, B.S. Purwoko, D. Wirnas, I.S. Dewi. 2014. Yield potential and stability, and adaptability of new plant type of upland rice lines developed through anther culture. J. Agron. Indonesia 42:9-16.

Rakshit, S., K.N. Ganapathy, S.S. Gomashe, A. Rathore, R.B. Ghorade, M.V.N. Kumar, G. Ganesmurthy, S.K. Jain, M.Y. Kamtar, J.S. Sachan, S.S. Ambekar, B.R. Ranwa, D.G. Kanawade, M. Balusamy, D. Kadam, A. Sarkar, V.A. Tonapi, J.V. Patil. 2012. GGE biplot analysis to evaluate genotype, environment, and their interaction in sorghum multi-location data. Euphytica 185:465-479.

Rasyad,A., Idwar. 2010. Genotype × environment interaction of yield components and stability of several soybean genotypes in Riau Province. J. Agron. Indonesia 38:25-29.

Rea, R., O.D. Sousa-Vieira, A. Diaz, M. Ramon, R. Briceno, J. George, M. Nino, L.B. Balzano-Nogueira. 2016. Genotype-environment interaction, mega environment and two-table coupling methods for sugarcane yield studies in Venezuela. Sugar Tech. 18:354-364.

Rincent, R., E. Kuhn, H. Monod, F.X. Oury, M. Rousset, V. Allard, J. le Gouis. 2017. Optimization of multienvironment trials for genomic selection based on crop models. Theor. Appl. Genet. 130:1735-1752.

Sibiya, J., P. Tongoona, J. Derera. 2013. Combining ability and GGE biplot analyses for resistance to northern leaf blight in tropical and subtropical elite maize inbred lines. Euphytica 191:245-257.

Suwarto. 2010. Genotype by environment interaction of rice Fe content. Dissertation. Post Graduate Program, Faculty of Agriculture. Gadjah Mada University. Yogyakarta. Unpublished.

Szareski, V.J., T. Pedó, V.Q. de Souza, F. Lautenchleger, G.H. Demari, M. Nardino, A.M. Levien, K. Kehl, I.R. Carvalho, T.Z. Aumonde. 2017. Univariate, multivariate techniques and mixed models applied to the adaptability and stability of wheat in the Rio Grande do Sul State. Gen. Mol. Res. 16:1-13.

Tariku, S. 2017. Evaluation of upland rice genotypes and mega environment investigation based on GGEBiplot analysis. J. Rice Res. 5:1-7. 
Tukamuhabwa, P., H. Oloka, T. Sengooba, P. Kabayi. 2012. Yield stability of rust-resistant soybean lines at four mid-altitude tropical locations. Euphytica 183:1-10.

Ullah, H., I.H. Khalil, Durrishahwar, Iltafullah, I.A. Khalil, M. Fayaz, J. Yan, F. Ali. 2012. Selecting high yielding and stable mungbean genotypes using GGE biplot techniques. Can. J. Plant Sci. 92:951-960.

Yan, W. 2001. GGE biplot - A Windows aplication for graphical analysis of multienvironment trial data and other types of two-way data. Agron. J. 93: 11111118 .

Yan, W. 2002. Singular value partitioning in biplot analysis of multi environment trial data. Agron. J. 94:990996.
Yan, W., I. Rajcan. 2002. Biplot analysis of test sites and trait relations of soybean in Ontario. Crop Sci. 42: 11-20.

Yan, W., L.A. Hunt, Q. Sheng, Z. Szlavnies. 2000. Cultivar evaluation and mega-environment investigation based on GGE biplot. Crop Sci. 40:597-605.

Yan, W., L.A. Hunt. 2002. Biplot analysis of diallel data. Crop Sci. 42:21-30.

Yan, W., M.S. Kang, B. Ma, S. Woods, P.L. Cornelius. 2007. GGE biplot vs. AMMI analysis of genotypeby-environment data. Crop Sci. 47:643-655. 